\title{
Third Cinema Approach and Anti-Colonial Theory: Two trains towards one destination (A Comparative Study of Sidhwa's Ice-Candy-Man and Deepa Mehta’s Earth 1947)
}

\author{
Muhammad Farooq ${ }^{*}$, Mustanir Ahmad and Athar Farooq
}

English Department, Hazara University, Mansehra, Pakistan

*Corresponding Author: Farooq M, English Department, Hazara University, Mansehra, Pakistan, Tel: +923331965458; E-mail: englishliterature35@gmail.com Received date: July 06, 2017; Accepted date: July 14, 2017; Published date: July 20, 2017

Copyright: ( 2017 Farooq M, et al. This is an open-access article distributed under the terms of the Creative Commons Attribution License, which permits unrestricted use, distribution, and reproduction in any medium, provided the original author and source are credited.

\begin{abstract}
This research paper is an effort to analyze the Third Cinema ${ }^{1}$ approach and Anti-colonial theory by a comparative study between Bapsi Sidhwa's Ice-Candy-Man and its visual adaptation Earth 1947 by Deepa Mehta. The paper explores the objectives of the mentioned theories/approaches and terms them as two trains towards one destination. The statement metaphorically refers to the geographical resemblance between the Anti-colonial theory and Third Cinema approach (as both deal with the issues of Third World countries) and ideological similarities between them in respect of their goals and aims. The article examines Anti-Colonial theory as a counter-narrative ${ }^{2}$ in the domain of Post-Colonial Studies. Similarly, it analyzes Third Cinema approach as a counter-projection in Third Cinema studies because it deconstructs the false and biased projection of the issues of Third World by dominant cinema and reconstructs a new version of projections based on reality. The paper shows that these theories challenge the notion of colonialism and create awareness among the suppressed and marginalized people and finally prepare them to take action, to define their identity and to resist against the colonial cruelties.
\end{abstract}

Keywords: Anti-colonial theory; Third cinema; Questioning cinema; Master-narrative; Counter-narrative

\section{Introduction}

Literature in the modern era is not confined just to the words printed on the page, but it makes a manifest appearance in the form of literature on screen, i.e. films and cinema. Cinema is a powerful weapon for the projection of various social, political and cultural issues. Being a medium, it contributes a significant part in the building and understanding about socio-political conditions of a society. Third world countries have produced a number of movies which reflect revolutionary nature. These movies based on decolonization and other debates, such as freedom of the Third World countries. Third Cinema, in this respect, plays its part for the projection of the issues of the Third World. In other words, it is a cinema which is oppositional to the popular Hollywood Cinema. It particularly discusses the political issues of the Third World, Latin American, African and the Asian countries that constitute a considerable part of the Third World and questions the hegemony of the Centre. Solanas and Getino [1] stated that:

Western films were primarily focused on generating profit and producing entertainment, while the movies produced in the Third World, were to be of a different kind and with a different aim. Third Cinema is moved by the concern of people who are threatened by colonial or neocolonial rule and conflicts, and the cinema is a response to the changes and events that the people in the Third World undergo. The filmmaker in Third Cinema is therefore inevitably committed to a certain ideological way of thinking.

Like Third Cinema, Anti-Colonial literary theory involves the literature written in the colonizing countries about the colonized nations. Anti- colonial functions as a counter-narrative and it challenges the master-narrative composed by colonizers which misrepresented the colonized people as "other", quoted in Said's Orientalism [2]. Anti-colonial resistance is a key issue in postcolonialism. History of colonialism is often misrepresented by the colonial writers for their personal benefits. Many of the travelers depicted biased estimate about other countries during their visit. In this regard history of partition in 1947 in India and Pakistan is falsely described by European and other colonial writers. This false version of history by colonial class stands as master-narrative. In response to master-narrative, the Post-Colonial writers and critics highlighted the falsely depicted areas, misrepresented by colonial writers. So they started writing in reply to master-narrative which challenges the misrepresented and this version of writing stands as counter-narrative where it reconstructs the identity, culture and location of colonized people.

The present research paper deals with a comparative study between Anti-Colonial theory and Third Cinema Studies. The article analyzes both the mentioned theories/approaches as two trains towards one destination. In other words it dwells upon the resemblance and similarities between them in respect of their goals and aims. It arises

$1 \quad$ The Third Cinema refers the films directed on the issues of the Third World countries such as India, Pakistan, Africa and Latin America. It is also termed as Counter-Cinema or Questioning Cinema because like anti-colonial theory it questions and challenges the master-narrative and the projection of Dominant Cinema i.e. Hollywood.

2 The term counter-narrative deals with the writings composed by colonized writers in response to master-narrative which refers to the writings composed by colonial writers in order to dominate their values and perceptions while. 
Citation: Farooq M, Ahmad M, Farooq A (2017) Third Cinema Approach and Anti-Colonial Theory: Two trains towards one destination (A Comparative Study of Sidhwa's Ice-Candy-Man and Deepa Mehta's Earth 1947). Arts Social Sci J 8: 285. doi: $10.4172 / 2151-6200.1000285$

Page 2 of 6

questions such as what are the ideological similarities between Third Cinema and Anti-Colonial Theory. And how both theories/approaches successfully depict and project the issues of Third World countries? The main aim of the present paper is to compare the geographical resemblance and ideological similarities between Third Cinema theory and Anti-Colonial theory in respect of their goals and aims. The subject matter in this paper is significant. It leads the reader audience to a new branch of literature, i.e. literature on screen, in the light of Third Cinema theory. The touch of third cinematic element creates consciousness in public because most of the people cannot study literature, but they have another option of watching certain issues on the screen in form of adaptation of the text. The Third Cinematic perspective in the present research further enables the reader to understand more lifelike projection of issues of Third World.

This paper rests on two major approaches/theories namely the AntiColonial theory and the Third Cinema approach. Anti-colonial literary theory, in present study has been employed to analyze the novel IceCandy-Man by Sidhwa [3] that how it stands as counter-narrative against the master-narrative. While through the exercise of Third Cinema approach analyzes Mehta's Earth 1947 [4] as political film in the context of third Cinema. Further, a comparative study of anticolonial theory and Third Cinema studies throws light on similarities goals and aims between them.

\section{Literature Review}

Film study is a branch of art and literature with more convincing, satisfactory and life-like projection of literature on the screen. Film adaptation and literature are both independent disciplines, as Richardson states: "film and literature are essentially two different fields: what we all know, but what is worth restating is that what makes a good film does not make a good novel and what makes a good novel, does not make a good film, thus film is highly an act of individual cognition". Similarly, Bush and Harmon argue that Literature reflects that cinema is an effective instrument for projecting reality and representing society in its various forms. There are three important dimensions of cinema i.e. The First Cinema which focuses on consumption and commerciality and it is also known as Dominant Cinema. The Second Cinema refers to European art film and aesthetic sense, whereas the Third Cinema is politically oppositional to first two kinds of Cinema. It specifically deals with the issues of the Third World countries such as Africa, Asia and Latin America.

The Third Cinema was initially introduced by Theshom Gabriel in 1960s and 1970s and it projects the socio-political issues of the Third world (Asia, Africa and Latin America) on the screen. Third World indicates to the colonized, neo-colonized or decolonized of the world whose economic and political structures have been shaped and deformed within the colonial process [5]. The concept of Third Cinema is highly revolutionary and political in nature. Ramsay argued that Third Cinema films make revolution on the ideological level with a new film style. Third Cinema debates the following areas; such as it questions the power structure (colonialism) and aims for the freedom of oppressed in the context of gender, class, race, religion, and identity problem of Diaspora population. Third Cinema projects the cultural clash among different nations living in one geographical position. The Third Cinema like revolutionary film sought to integrate theory and practice. According to Birri, the Argentinian filmmaker who revolutionized documentary filmmaking in that country inspired for a cinema that awakens and invites a revolutionary consciousness it is a cinema that is anti-bourgeois at the national level and anti-imperialist at an international level and it intervenes in the process of creating new people, societies, and new histories. The Hour of the Furnaces [6], directed by Getino and Solanas [6,7] is considered to be the first Third Cinema film. Both directors are considered to be the fathers of Third Cinema on the basis of such striking documentary. Carrying their manifesto of this documentary is influential among rest of the revolutionary films, because it involves the audience in the action and subverts them from imperialism through the projection of political and ideological issues. Solanas and Getino [5] wrote a manifesto regarding a movement of a new kind of cinema, i.e. Third Cinema, a cinema this new cinema which particularly projects the issues of the Third World countries. In the opinion of mentioned writers, Third Cinema is an alternative to Hollywood- First Cinema and European experimental art films- Second Cinema, because both of these did not reflect the realities of Third World countries. They represented Third Cinema as alternative source of projection which projects the exploitation, suffering and the realities of Third World. Similarly in the words of Wayne [8], the major aim of Third Cinema is to awake and to politicize the spectators in order to inspire and create a kind of revolution that may liberate the colonized nations. "Third cinema is experimental, and impels its audience toward social change: spectators become actors, the authors of history" The film act means an open-ended film; it is essentially a way of learning". Thus, as opposed to traditional cinema, third cinema is "cinema fit for a new kind of human being, for what each one of us has the possibility of becoming". The Third Cinema movement therefore represents a consciousness of the history-making and knowledge-making aspects of film and understands the historical role of cinema as creating a liberated society. The function of Third Cinema, while centrally concerned with the objective transformation of society, is not only extrinsic to viewing subjects but intrinsic as well. For all of the debates that have occurred over the tenability and fate of third cinema, the urgent call of Solanas and Getino [5] may yet be heard: "The decolonization of the filmmaker and of films will be simultaneous acts to the extent that each contributes to collective decolonization. The battle begins without, against the enemy who attacks us, but also within, against the ideas and models of the enemy to be found inside each one of us". Third cinema was to be filmmaking that would aid nationalist movements in creating a new sociocultural solidarity in the struggle against Western imperialism and for national self-determination.

The Third Cinema offers significant means of projecting the sociopolitical reality through the analysis of documentaries, such as The Battle of Chile and The Battle of Algiers. Its key aim is anti-oppressive worldview which contests the status-quo of political and social power; it demystifies the myth about colonized countries and questions the history, falsely constructed by colonial power. It reconstructs the history and this process of cinematic deconstruction is a powerful tool to reflect questioning nature of Third Cinema. The main aims of Third Cinema were firstly self-conscious-ideological opposition to Hollywood. Wayne [8] argues: "All films are political, but films are not all political in the same way". An advanced and sophisticated body of political films which produced as up to date is Third Cinema. Similarly, Jean Louis and Narboni in film magazine Cahiers du Cinema, argue that every film is political. The statement is very broad; The Oxford English Dictionary illustrates the word "political" means, "relating to the government or public affairs of a country". So, it depends on and is determined by the ideology, it produces.

Secondly to restore the identification with national liberation Willemen argues: "if any cinema is determinedly national even regional in its address and aspiration, it is Third Cinema". At the time of its 
Citation: Farooq M, Ahmad M, Farooq A (2017) Third Cinema Approach and Anti-Colonial Theory: Two trains towards one destination (A Comparative Study of Sidhwa's Ice-Candy-Man and Deepa Mehta's Earth 1947). Arts Social Sci J 8: 285. doi: $10.4172 / 2151-6200.1000285$

Page 3 of 6

release, Gabriel stated [1] "it raises the consciousness of its audience". Third Cinema provides a source of resistance for the oppressed people. The history of sexuality: the will to knowledge Foucault declares that:

Where there is power, there is resistance, and yet, or rather consequently, this resistance is never in a position of exteriority in relation to power.. Their power relationships' existence depends on a multiplicity of points of resistance... These points of resistance are present everywhere in the power network. Hence there is no single locus of great refusal, no soul of revolt, source of all rebellions, or pure law of the revolutionary. Instead there is a plurality of resistances, each of them a special case: resistances are possible, necessary, improbable; others that are spontaneous, savage, solitary, concerted, rampant, or violent; still others that are quick to compromise, interested, or sacrificial; by definition, they can only exist in the strategic field of power relations.

In Foucault's view power causes the resistance as in the case of colonialism the colonized with the passage of time started to struggle against hegemonic power and got somehow succeeded as well.

Like Third Cinema, the field of Post-colonial-studies provides a significant contribution in understanding the socio-political and cultural values of the Third World. In regard to its anatomy, it can be traced back to the western academy from the publication of Edward Said's influential critique of western construction of the orient in his book Orientalism [2]. As a genre of contemporary history, Postcolonialism questions and re-invents the modes of cultural perception the ways of viewing and of being viewed. As anthropology, it records human relations among the colonial nations and the subaltern peoples exploited by colonial rule. Anti-Colonial theory is one of the key areas of post-colonialism and it challenges the legacy of colonial power which does exist in literary writings. In the words of Bill Ashcroft PostColonial theory is a discussion of "migration, slavery, suppression, resistance, representation, difference, race, gender, place and responses to the influential master discourses of imperial Europe and the fundamental experiences of speaking and writing by which all these come into being" According to Bhabha 'Postcolonial criticism bears witness to the unequal and uneven forces of cultural representation involved in the contest for political and social authority within the modern world order'. This is an admirable ambition and very much within the tradition of the cultural imperialism model. The problem however is that the methodologies which post-colonial criticisms are wedded to are largely in conflict with this ambition. Anti-colonial theory has been influenced by post-Structuralism, a linguistic theory which argues that meaning is generated by difference and Postmodernism, which argues that culture, with all its plastic, malleable and shifting qualities, is the all-powerful and embracing force and model of the (post)modern era. Both influences are highly relativistic, providing little foundation on which to organize a politics of progressive change, and both are profoundly idealist in the philosophical sense that it is ideas, values, beliefs, or to use the preferred term, discourses that constitute the ultimate horizon of explanation.

Anti-colonial theory is about discoursing on difference, power, racial and socio-political oppressions. In the views of Larbalestier, "difference is both a conceptual, cultural and material problem. It is embedded in a politics of identity which are in turn, embedded in relation of power" anti-colonial thinker namely Albert Memmi long ago informed about the process of othering, which is about the construction of imaginary differences as real. This was followed by assigning social values to these differences, e.g. one can be perceived as being lazy, inferior, unintelligent and uncivilized. Similarly, an anticolonial theorist, Aime Cesaire spoke of the question of colonization with the notion of "thingification", and it is to be seen when radicalized bodies e.g. Blacks and Aboriginals are objectified through the continual denial of their basic humanity as Conrad's Heart of Darkness shows. In the view of Mignolo the concept of Western socalled civilization mission works as Euro-centrism, as he argues.

Coloniality of power means that all dominated populations and all the newly created identities were subjected to the hegemony of Eurocentrism understood as a way of conceiving of and organizing knowledge, above all, when some sectors of the dominated population had the opportunity and the chance to learn the writing system of the colonizer.

Anti-Colonial literary theory particularly deals with reading and writing of literature written in colonized countries or literature, written in colonizing countries. It challenges the master-narrative composed by colonizers which misrepresented the colonized people as "other", in words of Said's Orientalism [2]. Secondly, it functions as counternarrative by the colonized writers. Anti-colonial resistance is a major issue in post-colonialism. The colonial experience is a continuing process even after the formal end of the colonial situation. AntiColonial struggles, therefore, must challenge colonialism at political, intellectual and emotional levels. History is often misrepresented by the colonial writers for their personal benefits. Most of the travelers depicted biased estimate about other countries during their visit. In this regard history of partition in 1947 in India and Pakistan is falsely described by European and other colonial writers. This false version of history by colonial class stands as master-narrative. In response to master-narrative, the Post-Colonial writers and critics highlighted the falsely depicted areas, misrepresented by colonial writers. So they started writing in reply to master-narrative which challenges the misrepresented and this version of writing stands as counter-narrative where it reconstructs the identity, culture and location of colonized people. Post-colonial literary theory largely based on the concept of "otherness" where post-colonial critic, Said argues in Orientalism [2], that Western have placed the eastern outside the world by objectifying and labeling as "other". Anti-colonial thought is about a "decolonizing of the mind" and this element is done with resistant knowledge and claiming the power of local subjects' intellectual agency. This resistance is to fight for survival of oppressed ones. In this context, language is a powerful tool for decolonization. Through the use of language as resistance the anti-colonial writers deconstruct the master-narrative and present alternatively a counter-narrative and this is what the core function of anti-colonial theory like the Third Cinema approach in film studies.

\section{Analysis and Discussion}

\section{Ice-candy-man as anti-colonial text for Mehta's Earth 1947: Ideologically a third cinema film}

In $\mathrm{ICM}^{3}$ the novelist presents socio-political realities in India and Pakistan during the partition of 1947. She discusses several sociopolitical issues with the help of creative aesthetic sense. ICM is considered to be more neutral and near to the reality on the partition of Sub-Continent. Sidhwa [3] being experiencer of partition of 1947

3 In this paper ICM has been used as an abbreviation of Sidhwa's novel Ice-Candy-Man. 
Citation: Farooq M, Ahmad M, Farooq A (2017) Third Cinema Approach and Anti-Colonial Theory: Two trains towards one destination (A Comparative Study of Sidhwa's Ice-Candy-Man and Deepa Mehta's Earth 1947). Arts Social Sci J 8: 285. doi: $10.4172 / 2151-6200.1000285$

Page 4 of 6

has captured the turmoil partition with brilliant combination of individual as well as collective anguish of the society. The novel is a political text as it shows the consequences of political decisions. Sidhwa paints a vivid picture of the political scenario when the nationalists were struggling to break the country into two portions. She also shows ambivalent attitude of the Parsi community towards the shift of power in 1947. She presents the Parsees as cultural hybrids. Sidhwa [3] argues that through her writings she has tried to give a voice to her readers in Pakistan along with a sense of self-esteem. Sidhwa's [3] novel provides voice to those who were ignored or neglected; for instance Jinnah's political capabilities were neglected by anti-Pakistani writers. Similarly, negatively Muslims were blamed for destructive partition. ICM tries best to describe the issues of the partition and creates awareness among the people. After reading the novel the reader comes to know about the scenario of partition of 1947. Sidhwa [3] felt intense need to re-write about the history of partition due to her dissatisfaction with previously written versions of partition of sub-continent and this need she reveals in her interview where she argues that she is optimistic about her writing being a source of empowerment for voiceless people, she spoke with Montenegro as under:

At least, I think a lot of readers in Pakistan, especially with ICM feel that I've given them a voice, which they did not have before. They've always been portrayed in a very unfavorable light. It has been fashionable to kick Pakistan, and it's been done again and again by various writers living in the West and I feel, if there's one little thing I could do, it's to make the people realized: we are not worthless because we inhabit a poor country that is seen by Western eyes as a primitive, fundamentalist country only.

The above mentioned lines of the writer reflect her intentions behind the composition of the novel ICM. The novel functions as an anticolonial text because it questions those texts composed by colonial writers which exhibit biased versions on the event of partition. Sidhwa's [3] ICM is source of empowerment for the people of Pakistan. ICM empowers its reader and defines his/her identity. As the West often leaves misconception about the East and this misrepresentation has been questioned by Sidhwa [3]. In ICM, Sidhwa [3] deals with various themes, different characters, voices, cultural varieties, communal conflicts and quest for burdened identity, intertextualized skillfully. The title of the novel as Cracking India directly relates the history of partition and politics. The novel is a powerful discourse and it deals with multiple histories, of nations, of communities and of individuals as well. The political upheaval during the traumatic event of partition in the Sub-Continent, during the British region, developed into regional identities to be achieved through border making. Sidhwa in the novel has used first person narrative as a device to re-write the history of the sub-continent by undercutting the British views of history imposed on the sub-continent. The anti-colonial era provided new inspiration to the writers like Sidhwa [3] to have graphic record of the past of the nation of communities and of individual in ICM. She has rejected the earlier version of history of partition inked by British Colonial Power. The novel particularly deals with the historical event of partition of 1947 in Sub-Continent that ends up with division of sub-continent into two halves- India, a Hindus controlled homeland and Pakistan, a Muslims controlled homeland.
On the basis of literature review, where I made discussion in respect of Third Cinema, the film, Earth $1947^{4}$ [4] manifests itself as a Third Cinema film. Most of the elements, styles, aims and features which the Third Cinema bears can be traced down in the film Earth 1947 [4]. Further, Earth 1947 is political film in respect of its ideological perspective. So this chapter discusses about Mehta's film Earth 1947 [4] as political film in the context of Third Cinema.

Mehta's 1947 Earth [4] is adapted version of Pakistan's diasporic writer, Sidhwa's ICM. The novel depicts the traumatic period of partition of 1947 in Sub-Continent. The film Earth like the source text, ICM focuses on the disastrous happening of partition of united India into modern India and Pakistan. The film particularly deals with questions such as, what was the need of partition, why centuries' friends turned enemies. Why women bodies are celebrated? All these issues are debated by the director, Mehta in her film Earth, 1947 [4] through Third Cinema approach. Earth 1947 [4] works as questioning cinema and its main end is to review the blind projection by colonized film-maker about the history of partition in Sub-Continent. Mehta's Earth 1947, [4] like Third Cinema questions the existence of colonialism and reconstructs the identity of those who were objectified. In this way the film brings revolution by spreading the element of ideological consciousness among its audience. In the views of Solanas [5] and what defines the revolutionary act in film is not the form in which it is expressed, but the transformative role on the basis of ideology. Earth 1947 [4] implies different third cinematic element which are to be discussed in below.

History, at the textual level, is an open ended site of conflict and change as it can be compared to Spielberg's Amistad with Alea's The Last Supper and Sembene's Camp de Thiaroye. The Third Cinema seeks to develop the means for grasping history as process, change, contradiction and conflict, in short the dialect of history. Benjamin quotes that "history is great explainer, where we are, why we are and who we are?" The film Earth 1947 [4] is basically a record of history of partition in Sub-Continent. In this context both the writer, Sidhwa [3] and the Director, Mehta re-write the history of partition in India and Pakistan. This process of re-writing the history of partition functions as historicity in the film. Moreover, Earth 1947 [4] being political film in the context of Third Cinema film, questions the colonial policy of 'divide and rule'. In the very opening of the film Lenny's breaking the plate symbolically implies the British's breaking the Sub-Continent. Mehta deconstructs the history in order to reconstruct the identity of people and she by doing so empowers the audience with consciousness. The Third Cinema films are highly politicized and revolutionary in nature. They deal with the account of oppressed and the oppressors. Third Cinema is also termed as revolutionary cinema, as in words of Birri "a revolutionary cinema is one that is all about to awaken political consciousness in its spectators", and Earth 1947 does bear this element. The concept of awakening the political consciousness in Third Cinema films is obviously taken from Frantz Fanon's work The Wretched of the Earth [9]. In Mehta's Earth there is struggle for power among different groups such as Muslim, Sikh and Hindu. The British Raj comes to end in Sub-Continent and the decline of imperialism is the key theme in both the novel and its adapted version Earth 1947 [4]. Being Third Cinema, the film questions the identity of different communities within nation and diasporic population, who migrated from their land because of exile or killing.

4 Mehta's Earth 1947 is a cinematographic adaptation of Sidhwa's Ice-Candy-Man. The film projects the history of partition of 1947 in Sub-Continent. The film is ideologically a Third Cinema movie because it projects the issues of politicized history of sub-continent during the era of partition of 1947. 
Citation: Farooq M, Ahmad M, Farooq A (2017) Third Cinema Approach and Anti-Colonial Theory: Two trains towards one destination (A Comparative Study of Sidhwa's Ice-Candy-Man and Deepa Mehta's Earth 1947). Arts Social Sci J 8: 285. doi: $10.4172 / 2151-6200.1000285$

Page 5 of 6

Earth 1947 [4] is about how imposed political decisions can tear apart communities which had reached their own internal balance and, following a group of individuals it chronicles one of the scars of India and Pakistan's history. It depicts the tension and the resulting violence surrounding the British division of the country into an independent India and Pakistan.

The movie projects the suffering of people on the screen where approximately ten million people migrated across the border, thousands of the people were killed and innumerable of people became homeless. Similarly, minorities faced a lot of issues as in the film Parsee community is a minority group. The Parsee community feels danger being a minority group and shows passive attitude towards the partition of Sub-Continent. The president of Parsee community warns his community in ICM as below: "Let whoever wishes rule, Hindu, Muslim, Sikh, Christian we will abide by the rules of their land". In the film political and nationalist narratives are disrupted when young Lenny deliberately breaks a plate. The apparent child-like action of Lenny suggests her internal rage regarding the British and nationalist politicians' decision to divide the country on basis of religion and demonstrates, through her actions, that such an action will effectively destroy, "smash" the unity of the country. Lenny's subsequent question to her mother, whether one can break a country, is an example of her innocent intervention into the political actions of dividing human relationships on the basis of religion. Through her portrayal of Lenny's symbolic action and questioning of the breaking of the country through her question, Mehta [4] criticizes both the British and nationalist leaders' sectarian decision. As she argues:

There are many dark political questions about partition that the British establishment doesn't want bring to light. When you know the real history of partition and the responsibility that lands in the laps of the British, obviously you understand why it is a very uncomfortable subject for them. Generally the response there has been to romanticize Gandhi and Lord Mountbatten. This is done to such a degree that quite nauseous (Phillips).

Mehta's critiques of British and Indian elite nationalist ideologies regarding partition are evident in the dinner scene in this film. It is the only scene where we see the direct presence of British Raj. In this scene, the British bureaucrat Roger, Sethna, and his elite nationalist Sikh guest engage in violent debate over who will rule India and what will happen if the British government leaves. This scene focuses our attention on the dominant perspectives about India's partition liberal, nationalist and British perspectives. For example, Mr. Roger points out arguments in favour of British rule in India to protect Indians from division; on the other hand, Sethna's elite nationalist friend blames British government for the total mess and problems, while Sethna argues that a neutral position is the best position. What is clear in this scene is the absence of women and subaltern groups in the discussion, symbolized by Lenny's position 'beneath' the table. By completely excluding subaltern and women's opinions from these dominant perspectives in the dinner scene, Mehta highlights a 'gap' in the dominant approach of history writing: "whose or what history is represented". Similarly, Ayah shows her political consciousness regarding the effect of the partition in India and Pakistan at the very beginning of the film: explaining the British motives regarding the partition, she explains to Sethna in Earth as "Madam, I hear, before giving us independence, the British will dig a huge canal. On one side Hindustan, the other side, Pakistan [4]".

Ayah's statement suggests the political motives of the British government not only to separate India into two countries, but also to reinforce the growing conflicts between Hindus, Muslims and Sikhs on basis of religious discourses. Whenever the imperialist culture progresses, it destroys the national culture and consequently foreign culture dominates the local culture. One of the key aims of Third World filmmakers is to struggle in order to preserve the cultural make up of a society. In this regard the Third Cinema contributes a significant role and that is the aesthetics of liberation. Third World filmmakers have realized the importance of incorporating traditional art forms to retain the distinctive flavor of popular mass culture; Third World countries have two distinctively parallel cultures [10].

The ruling classes emulate a culture co-opted by colonial and imperialistic values, which is in direct conflict with the culture of the people. One of the distinctive characteristics of Third Cinema is the importance it attaches to the question of culture. Culture is a crucial realm where identity, belief and values are forged, while the Third Cinema intervenes in culture as a site of struggle. One of the channels through which a democratic culture of the masses gets articulated is popular memory. Gabriel finds some links between popular memory and Third Cinema. Both, the Third Cinema and popular memory emphasize a history in which individual is deeply linked to the world around him or her. It is the people and not a few individuals who make history. History explores how culture is site of political struggle. History shows clearly that one of the things which imperialism and colonialism attempted to control in parallel with economic resources is culture. The Third Cinema is not a parochial defense of native or indigenous culture: its attention to class differences and its internationalism helps guard against that. Fanon, warned against the uncritical celebration of the native's culture as much as he warned against the uncritical assimilation of the culture of the colonialists. In the opinion of Fanon the production of culture is a necessity because: 'Culture is the first expression of a nation, expression of its preferences, of its taboos and of its patterns the condition for its existence is therefore national liberation. This is precisely the aim of Third Cinema to move the audience and create a process of mobilization and awakening. At this point Third Cinema touches the boarder of Postcolonial theory and its master concept of hybridity. Bhabha's debates on the stereotype in particular and its consequent modes of representation discussed in "The location of Culture", is the key element of Earth film. In the view of Bhabha, the stereotype is an ambivalent mode of knowledge and power and this ambivalent mode sense is manifested hybrid identity being Indo-Canadian is implied. Earth 1947 [4] is Mehta's deliberate challenge to the Western filmmakers where she does not only provide a simple revision or refusal of stereotype rather she systematically and logically reveals that how the stereotype works through colonial thinking. Earth 1947 [4] does not only aware its audience about their identity and position but it stimulates them to ponder, to peep in and to relocate themselves [11-13].

In the film Earth 1947, cultural difference works as political power. In the film different cultural groups such as Hindu, Muslim and Sikh are struggling for their national liberation and culture functions as political struggle. Hindu, Sikh and Muslim are jogging for power and their respective sects become poison for one another as Lenny comments "ones religion is poison for other" [3].

\section{Conclusion}

The present research paper concludes that Anti-Colonial theory and Third Cinema approach have got something common in respect of their goals and aims. The current paper has made a comparative study 
Citation: Farooq M, Ahmad M, Farooq A (2017) Third Cinema Approach and Anti-Colonial Theory: Two trains towards one destination (A Comparative Study of Sidhwa's Ice-Candy-Man and Deepa Mehta's Earth 1947). Arts Social Sci J 8: 285. doi: $10.4172 / 2151-6200.1000285$

Page 6 of 6

between anti-colonial theory and Third Cinema approach. Anticolonial theory works as counter-narrative against the masternarrative: it deconstructs the latter and reconstructs the history, culture and the identity of the colonized people of the Third World. Further geographically, Anti-colonial theory discusses the socio-political issues of the Third World countries which once had remained under the colonial power of the West. Like anti-colonial theory, Third Cinema approach also implies the similar goals and aims. It, like the anticolonial theory, works as counter or questioning cinema. It rebukes the Dominant Cinema (Hollywood) and constructs a new version of history of the Third World's people according to their original identity. Moreover, like anti-colonial theory it also geographically and ideologically discusses the issue of Third World countries. So both the discussed theories/approaches have similar issues with same goals and aims.

By concluding the discussion on Mehta's Earth 1947, [4] it is clear that it is Political/Revolutionary film in the context of the Third Cinema. The film implies a number of Third Cinematic elements such as politicization, revolutionary nature, aims and ideology of Third Cinema. Earth 1947, [4] projects the issues of India and Pakistan particularly of partition 1947 and it creates socio-political awareness among its spectators. Further, the main mission of the director, Mehta is clear enough form her interview as she admits the fact that the main aim of the film is to articulate the voiceless people with voice and to make them able for defining their position and identity. In short, after analysis of Mehta's Earth, [4] in the light of abovementioned discussion, the film suggests different Third Cinematic elements and it is political film in the context of the Third Cinema. While Sidhwa's ICM [3] serves as a source text for Mehta's Earth, [4] because it is the novel which stimulates the director to present the issues of partition in the shape of film's projection and as this fact has already been mentioned above where Mehta herself acknowledge the fact that she got inspiration for her film Earth from Sidhwa's ICM [3].

\section{References}

1. Gabriel TH (1982) Third cinema in the third world: The aesthetics of liberation. UMI Research Press, Ann Arbor.

2. Edward S (1978) Orientalism. Vintage Books, United States.

3. Sidhwa B (1988) Ice-candy-man. Milkweed Editions, London.

4. Mehta D (1998) Earth 1947. Giles Nuttgens Press, Dehli.

5. Solanas F, Getino O (1969) Towards a third cinema. Detroite.

6. Getino O, Solanas F (1968) The hour of the furnaces. Argentina Press.

7. Getino O, Solanas F (1971) Towards a third cinema. Cineaste.

8. Wayne M (2001) Political film. Pluto Press, London.

9. Fanon F (1961) The wretched of the earth. Grove press, New York.

10. Conrad J, Murfin RC (2010) Heart of darkness. Macmillan.

11. Fanon F (2008) Black skin, white masks. Grove press, New York.

12. Freire P (1968) Pedagogy of the oppressed. Foreword in Freire, Paulo, New York.

13. Glauber R (1965) Esthetic of hunger. Milan, Rio, New York. 